\title{
Kold krig
}

\section{Klaus Carsten Pedersen}

Dette massive værk, som har været fem år undervejs, er et uomgængeligt bidrag til indsigt i en historisk epoke, som vi - næsten - har lagt bag os. Det bør ikke overraske, at mange af forfatternes valg og vurderinger kan diskuteres

Danmark under den kolde krig 1-4. Dansk Institut for Internationale Studier. København 2005. Ca. 2.350 s.

Den 30. juni offentliggjorde Dansk Institut for Internationale Studier (DIIS) sin udredning Danmark under den kolde krig. Udredningen er et massivt værk i fire bind med i alt 2.350 sider, inkl. flere tusinde henvisninger og 150 sider bilag, kildefortegnelse og indeks. Til pressen udsendte DIIS syv sider med udredningens hovedpunkter, og man kan formode, at disse syv sider var udgangspunkt for den megen medieomtale og den kortvarige, men livlige debat, som udspandt sig på tærsklen til sommerferien. Debatten drejede sig overvejende om firsernes fodnotepolitik. Medlemmer af og sympatisører med det daværende "alternative sikkerhedspolitiske flertal" følte, at udredningen havde gi- vet fodnotepolitikken et anerkendende klap på skulderen.

I sommerens løb ser et antal entusiaster ud til af have gnavet sig igennem værket, og her i september er den egentlige debat gået i gang med møder mellem udredere og mere eller mindre kritiske kommentatorer i bl.a. Selskabet for Samtidshistorisk Forskning og Det Udenrigspolitiske Selskab. Debatten skal ikke anmeldes her, og vi har vel også kun set begyndelsen af det lange, seje træk.

I betragtning af det enorme arbejde, som en håndfuld udredere har præsteret gennem fem år, må det være på sin plads allerførst at se på, hvad de egentlig blev bedt om.

Kommissoriet lyder i sin helhed:

"[Udredningen] skal belyse den sikkerhedspolitiske strategi og den militære trussel fra Sovjetunionen og de øvrige Warszawapagtlande mod 


\section{LITTERATUR Kold krig}

Danmark og det øvrige Vesteuropa, herunder navnlig de øvrige vesteuropæiske NATO-lande.

Udredningen bør indeholde en beskrivelse og vurdering af den kvantitative og kvalitative konventionelle styrkeopbygning i Sovjetunionen og andre Warszawapagtlande over perioden med særligt henblik på at beskrive truslen i form af et angreb på Vesteuropa og i forbindelse hermed truslen mod dansk territorium. Den sovjetiske udvikling og deployering af nukleare våben og andre masseødelæggelsesvåben og disses fremføringsmidler bør endvidere beskrives, ligesom sovjetiske kendte doktriner for anvendelse af våben, samt de overordnede sovjetiske overvejelser vedrørende opbygning og anvendelse af nukleare styrker bør beskrives.

Endvidere bør udredningen omfatte Warszawapagtlandenes politiske aktiviteter. Det gælder både den officielle politik og andre aktiviteter, som var rettet mod Danmark og de andre nordiske lande. Sovjetiske regerings- og partiorganers rolle i formuleringen af den overordnede strategi over for Danmark og de øvrige nordiske lande samt Forbundsrepublikken Tyskland bør søges beskrevet sammen med en redegørelse for KGB's, GRU's og øvrige efterretningstjenesters rolle. Overordnede politiske og militærstrategiske overvejelser i Warszawapagtlandene om påvirkning af Danmarks NATO-politik bør også belyses.
Endelig bør udredningen omfatte en gennemgang af den officielle danske sikkerhedspolitik og den danske sikkerhedspolitiske debat med særlig vægt på perioden hen imod den kolde krigs afslutning. Warszawapagtlandenes forsøg på at opnå direkte eller indirekte indflydelse, herunder gennem danske partier og organisationer m.v., på den danske debat og politikfastlæggelse på det udenrigs- og sikkerhedspolitiske område er i den forbindelse af særlig interesse. Warszawapagtlandenes vurdering af den førte sikkerhedspolitiks indflydelse på det danske forsvarsberedskab og Danmarks stilling i NATO ønskes også belyst sammen med en belysning af Danmarks NATO-allieredes vurderinger og overvejelser i relation til Danmark."

\section{Strukturen}

For at få hold på det omfattende materiale har udrederne for det første delt perioden 1945-1991 i tre dele, som har fået hver sit bind: Den tidlige kolde krig 1945-1962, Détente 1963-1978 og Sidste fase af den kolde krig 1979-1991. Denne periodisering kan diskuteres; men den kan sagtens forsvares, og bindene bliver i snit på ca. 700 sider. Det mere håndterlige bind 4 Konklusion og perspektiver giver en oversigt over truslen mod Danmark, den vestlige ramme for dansk sikkerhedspolitik og denne politik i nationalt perspektiv på i 
alt ca. 90 sider. Bind 4 rummer også 80 sider bilag, 60 sider kildefortegnelser og et register til alle fire bind på 20 sider.

For det andet er der valgt en emnemæssig systematik, som følges i alle tre periodebind: I rækkefølge behandles den internationale kontekst, den sikkerhedspolitiske debat i Danmark - meget omfattende - og formuleringen af dansk sikkerhedspolitik. Først derefter kommer kapitlerne om østlige aktiviteter rettet mod Danmark: strategier og kampagner, efterretningsvirksomhed og endelig den militære trussel mod Danmark. Sidst i hvert bind kommer de eksterne vurderinger af dansk sikkerhedspolitik, de vestlige og de østlige - og udredernes egne konklusioner.

Det er påfaldende, at systematikken er vendt på hovedet i forhold til systematikken i kommissoriet: Udrederne starter med den danske sikkerhedspolitiske debat og politik og ser først derefter på de problemer, som debatten og politikken formodes at handle om. Det forekomme umiddelbart ulogisk, men er måske et udtryk for, at debatten drejede sig om meget (alt?) andet end den østlige trussel mod Danmark. En pointe vi vender tilbage til.

For det tredje har udrederne valgt at analysere den kolde krigs parters politik, eller rettere skiftende politikker igennem hele forløbet i forhold til på den ene side "systemkonflikten” mellem Øst og Vest og på den anden side begge parters "sikkerhedsdilemma" (den enes sikkerhed er den andens usikkerhed og omvendt). Inden for denne ramme analyseres Danmarks sikkerhedspolitik med udgangspunkt i adaptionsteorien som et samspil mellem "balancepolitik" og "affindelsespolitik" såvel i forhold til alliancen som i forhold til modstanderen. Inden for disse overordnede adaptive orienteringer, der ses som meget stabile, beskrives et antal forskellige strategier, som varieres efter omstændighederne.

Man spørger sig selv, om den kolde krigs beslutningstagere var særlig bevidste om denne systematik eller om den velordnede strategiske værktøjskasse, som udredningen definerer for os. De af dem, som læser udredningen i dag og trænger igennem dens stedvis lidt overvældende akademiske kancellistil med det rige indhold af verbalsubstantiver og politologisk og militær fagterminologi, vil måske have svært ved at genkende deres egne overvejelser dengang. Apropos sproget er det stedvis interessant at se på, hvad man kunne kalde det verbale kropssprog. En sætning som "I 1955 blev delingen af Europa endeligt formaliseret med indlemmelsen af det nu genmilitariserede Tyskland i NATO og den sovjetiske oprettelse af Warszawapagten" har to minusord på vestsiden og ét neutralt ord på østsiden.

Udrederne har støttet sig på et omfattende samtidigt primærkilde- 


\section{LITTERATUR Kold krig}

materiale, heriblandt meget arkivmateriale, som ikke før har været tilgængeligt, fx fra FE og PET og fra Polen og DDR. Hertil slutter sig samtidigt presse- og debatstof og erindringslitteratur samt interviews med et antal af periodens aktører. Man bemærker, at der er fire V/K-politikere blandt de interviewede og femten fra De Radikale og venstrefløjen. Derudover er der anvendt en enorm mængde sekundære kilder; litteraturlisten er langtfra udtømmende, men rummer over 1.000 bøger og artikler. Det er aldeles imponerende, hvad udrederne har nået at læse og skrive i løbet af de fem år, der er medgået, også selv om der synes at være investeret 25-30 mandår i projektet. De gør undervejs omfattende rede for mange af deres kildeproblemer, metodeproblemer og fortolkningsproblemer for så vidt som de er opmærksomme på dem.

Men fortolkes og konkluderes skal der, og det bliver der også. Mangt kan man forstå og sympatisere med; men meget vækker til diskussion, og noget provokerer til modsigelse og afvisning. Her skal blot ganske kort og urimeligt forenklet refereres nogle af udredningens væsentligste konklusioner, og der skal knyttes en kommentar til hver af dem. Desuden vil et par specielle temaer blive trukket frem til nærmere beskuelse. Fokus er næsten udelukkende på udredningens bind 3 og 4, som den meste interesse, ros og kritik har samlet sig om.

\section{Truslen}

Konklusion: I den kolde krigs sidste fase overvurderede vi i Vest den sovjetiske trussel. Der synes i en vis forstand ikke at have været nogen, for så vidt som man ikke har kunnet finde dokumentation for, at Sovjetunionen på noget tidspunkt havde til hensigt at foretage et uprovokeret angreb.

Kommentar: Konklusionen tyder på en forenklet opfattelse af trusler og deres dynamik. Krige mellem nogenlunde jæunbyrdige parter begynder næppe med et planlagt uprovokeret angreb. Men de begynder nogle gange alligevel, fordi kriser udvikler sig, og situationer fejlfortolkes, eller fordi angriberen har en meget rummelig definition af, hvad der er en provokation. Udrederne hævder, at USA og dets allierede fejlbedømte truslen, fordi de kun så på den militære styrkeopbygning og ikke på modpartens mulige hensigter. Det var dog vist først den såkaldte Rumsfeld-rapport fra slutningen af 1990'erne, som roste sig af at have udviklet en helt ny og bedre "metode" i form af en trusselsvurdering, som så helt bort fra USA's potentielle modstanderes hensigter.

Under den kolde krig var princippet i efterretnings- og varslingstjenesternes trusselsvurdering, at truslen måtte anskues som et produkt af hensigt multipliceret med styrke, at styrke ikke kunne opgøres absolut, 
men kun relativt (modstanderens styrke divideret med egen styrke i en given geografisk og operativ sammenhæng), og for det tredje, at modstanderens hensigt selvfølgelig var påvirket af hans styrke. Der var også påvirkning den modsatte vej, for selvfølgelig var der en hensigt bag styrkeopbygningen.

Udredernes trusselsmodel er mindre stringent; men dens virkelige svaghed er, at den tilsyneladende overser, at styrken (som altså er relativ) lægger en praktisk ramme om de mulige hensigter. Til gengæld har de helt rigtigt fat $i$, at disse forskellige faktorer og især det komplicerede samspil mellem dem ikke let lader sig måle. I Danmark var der yderligere den komplikation, at Forsvarets Efterretningstjeneste (FE) kun skulle følge og vurdere Warszawapagtens hensigter og styrker, mens ansvaret for vurderingen af vore egne og vore allieredes styrker lå i Forsvarskommandoen, som også havde ansvaret for nettovurderingen. Det er i parentes bemærket således en forfejlet kritik, når udredningen et sted lidt spidst noterer, at FE "ikke ses at have forholdt sig" til amerikanske aktiviteter i Østersøen.

FE havde til gengæld et meget detaljeret og præcist overblik over Warszawapagtens styrker, bevæbning, deployering og øvelsesmønstre og en god ide om kvaliteten af udrustningen og personellets uddannelse og kvalitet. Tallene var meget store og de blev ved at vokse til den bitre ende. FE's hovedopgave var varsling, og for ikke at slide på troværdigheden gav man sig kun nødtvunget af med langsigtede prognoser; men man anså det allerede $\mathrm{i}$ 1979 for sandsynligt, at den sovjetiske økonomi ville nå grænsen for sin ydeevne i midten af 1980 'erne, og at radikale reformer da ville være nødvendige. (Når anmelderen ved dette så sikkert, er det fordi han selv udarbejdede prognosen til brug for Udenrigsministeriets og Forsvarsministeriet langtidsplanlægning.)

Der var mange tegn på, at den sovjetiske ledelse selv var klar over, at de økonomiske udsigter var dystre, men ingen tegn på, at det smittede af på forsvaret. Man måtte konstatere, at ledelsens prioritering af forsvaret var skyhøj, og at offerviljen på befolkningens vegne var stor. $\mathrm{Og}$ man var nødt til at regne med, at den militære formåen kunne smitte af på hensigterne, og at Sovjetunionen kunne optræde opportunistisk i forfølgelsen af sine mål: udbredelse af socialismen under sovjetisk lederskab og mere konkret: splittelse af den vestlige alliance.

I netop denne forbindelse kan vi i anledning af 200-året for H. C. Andersens fødsel mindes den sovjetiske hærs dagblad Røde Stjerne, som den 21. juni 1983 skrev, at de skandinaviske lande af USA var blevet tildelt rollen som Den Standhaftige Tinsoldat (der som bekendt røg i kakkelovnen). "I 'den atlantiske solidaritets' navn skal de brændes i kerne- 


\section{LITTERATUR Kold krig}

våbenkrigens bål”. Det var elegant grænsende til det poetiske at inddrage eventyrdigteren; for i klartekst ville man jo blot sige, at vi burde melde os ud af NATO, for ellers risikerede vi at blive udslettet af sovjetiske kernevåben.

En anekdote fra det virkelige liv til belysning af en professionel vurdering af truslen mod Danmark: Så sent som i efteråret 1987 mente nogle amerikanske militære planlæggere, som på American Defense University i Washington var sat til at nyvurdere de amerikanske forstærkningsplaner, at der var behov for en radikal forbedring af den planlagte forstærkning til det dansk-tyske korps i Slesvig-Holsten.

De var nået til den opfattelse, som allerede rådede i danske forsvarskredse, at det kunne være krigsafgørende at holde Jylland, men at netop Slesvig-Holsten var sårbart, fordi det lå på grænsen mellem to NATO-kommandoer, fordi to, ganske vist stærke, divisioner her stod over for fem Warszawapagtdivisioner i første echelon, og fordi den designerede amerikanske 9. Division ville være mindst en måned om at komme på plads. Så deres idé var, at halvdelen af Marinekorpset eller hele XVIII Luftbårne Korps burde designeres til Slesvig-Holsten og Jylland - 70.000-80.000 mand fremme på én til to uger med al udrustning. Mens de var i gang med at forsøge at overbevise de relevante chefer, brød freden ud.

\section{Sovjetunionens sammenbrud}

Konklusion: Hovedforklaringen på, at Sovjetunionen og dens pagtsystem faldt sammen, var det sovjetiske økonomiske systems ineffektivitet. En hjælpeforklaring var, at den amerikanske "sejrsstrategi" fra slutningen af 1970'erne i høj grad skærpede den sovjetiske ledelses erkendelse af systemets ineffektivitet. Strategien fremskyndede Sovjetunionens sammenbrud, men risikerede på den anden side at fremprovokere en sovjetisk militær panikreaktion med ødelæggende konsekvenser for alle parter. Dermed udgjorde USA og ikke Sovjetunionen den største fare i den kolde krigs sidste fase.

En anden (ligeværdig) hjælpeforklaring var, at Helsingfors-slutakten bidrog til at prikke små huller i jerntæppet og underminere kommunistregimernes autoritet, mens så forskellige folk som konservative og socialistiske ledere fra Europa og USA, amerikanske rustningskontroleksperter og europæiske fredsforskere alle leverede "konstruktivt imødekommende og brugbare bidrag til den sovjetiske omstilling".

Kommentar: Man kan vælge økonomisk svaghed som hovedforklaring. Men man kan også vælge som hovedforklaring, at sovjetledelsen var blevet forledt af sin egen ideologi og tradition til at spænde buen så højt i 1970'erne, at det fremprovokerede en dramatisk ændring i Vestens poli- 
tik fra afspænding til nyt våbenkapløb. At sovjetledelsen også havde ladet sig forlede af ideologien til at etablere et ineffektivt økonomisk system, som trods enorme ressourceindsatser helt åbenbart ikke ville kunne klare endnu en højteknologisk runde i våbenkapløbet, bliver så kun en hjælpeforklaring. For hvis Vesten ikke havde reageret, havde Sovjetunionen, Warszawapagten og den kolde krig formodentlig kunnet fortsætte i lang tid uanset de enorme spildprocenter i økonomien.

Hvis man kan acceptere dette ræsonnement, bliver den amerikanske "sejrsstrategi" hovedforklaringen på, at Sovjetunionen gav op. Desværre flytter udredningens fokus på den amerikanske politik i 1980'erne og udredernes formodninger om dens farlighed for os alle sammen opmærksomheden bort fra kursændringens årsag.

Amerikanerne opdagede jo omkring 1976-77, at Sovjetunionen trods - eller måske netop for at udnytte - den amerikanske afspændingspolitik i 1972-74 og kraftige nedrustning efter Vietnam-krigen fortsatte sin oprustning med uformindsket styrke på basis af støt voksende forsvarsudgifter. Den sovjetiske ledelse fremhæuede selv, at der i disse år skete en forskydning af styrkeforholdet mellem Sovjetunionen og USA til dens fordel. Den herved opnåede strategiske jævnbyrdighed er i øvrigt det eneste, som Gorbatjov nogensinde har rost Bresjnev for.
I disse år opstillede Sovjetunionen desuden en helt ny - og helt uprovokeret - kernevåbentrussel rettet mod Vesteuropa, som fik den socialdemokratiske tyske forbundskansler Helmut Schmidt til at råbe vagt i gevær, og den sovjetiske flåde blev kraftigt udbygget. Det strategiske formål var tydeligvis at afkoble Vesteuropa fra USA. Dertil kom, at Sovjetunionen på mange andre områder førte sig frem med aggressiv retorik, politik og militær optræden.

Alt dette tilsammen lignede en sovjetisk "sejrsstrategi"; men USA, som havde prøvet at være militært overlegen og nu jæunbyrdig, havde ikke lyst til at eksperimentere med den underlegenhed, som tendenserne pegede frem imod. Så USA besluttede at sætte foden ned og sine forsvarsudgifter op, udbygge flåden, opstille nye raketter i Europa rettet mod Sovjetunionen kombineret med et tilbud om at afstå, hvis de sovjetiske raketter blev fjernet - og endelig i marts 1983 at lancere en plan om et ekstremt højteknologisk forsvar mod raketangreb. Idéen var, og effekten blev, at gøre det fuldstændig klart for sovjetledelsen, at dens konfrontationspolitik og "sejrsstrategi" var uholdbar, især fordi den sovjetiske økonomi ikke ville kunne levere varen. USA's europæiske allierede sluttede med større eller mindre betænkelighed op om strategien - undtagen Danmark.

Hvis "sejrsstrategien" således vælges som hovedforklaring, kan freds- 


\section{LITTERATUR Kold krig}

folkenes og vort eget sikkerhedspolitiske flertals indsats højst blive en lillebitte hjælpeforklaring. Men der kan argumenteres for, at denne indsats faktisk forsinkede Sovjetunionens sammenbrud, og at sammenbruddet og den kolde krigs ophør måske slet ikke var kommet, hvis "fredspolitikken" havde haft held til at fortrænge "sejrsstrategien".

\section{Forbundne modsætninger}

Konklusion: "Resultatet endte med at blive sovjetimperiets sammenbrud på demokratiske præmisser. Medvirkende til dette resultat var indsatsen fra vidt forskellige og - hvis vi ser på yderfløjene - indbyrdes stærkt uenige grupper og personligheder i Vesten. Alle var de i en vis forstand interaktivt forbundet og nødvendige $\mathrm{i}$ en proces, hvis endemål de ikke kunne se, og hvis resultat de ville have forsvoret. I den forstand er der mange, der må deles om æren for det historiske resultat."

Kommentar: En smuk konstruktion, hvor analytikeren fra sit høje udsigtspunkt i bakspejlet ser de små menneskemyrer tumle rundt hver for sig i en overordnet koreografi, de ikke forstår, mod en fælles udgang, de ikke kan se. Postulatet, som man ikke behøver at acceptere, er at "sejrsstrategerne" må deles med "fredspolitikerne" om æren for Sovjetunionens sammenbrud og den kolde krigs ophør.
Det indebærer, at kombattanterne i 1980'ernes danske slagsmål om sikkerhedspolitikken i virkeligheden var interaktivt forbundne og lige nødvendige i den proces, hvis endemål de ikke kunne se. Det sikkerhedspolitiske flertals NATO-kritiske og Sovjet-hjælpsomme dagsordner og de fodnoter, som det tvang regeringen til at sætte under ellers enstemmige NATO-beslutninger, ydede deres bidrag til Sovjetunionens sammenbrud, og regeringens beroligelse af vore allierede og vort fortsatte bidrag til alliancens integrerede militære samarbejde ydede deres. Mange vil ikke lade sig overbevise af udredernes omfattende argumentation; men når enden er god, er selvfølgelig alting godt.

\section{Socialdemokratiet i 1980'erne}

Konklusion: Det socialdemokratiske kursskifte, som betingede det sikkerhedspolitiske flertal i 1982-1988, var baseret på en ny, kvalificeret analyse af den kolde krigs risici og afspændings- og fredspolitikkens muligheder, og den var forankret i Scandilux-samarbejdet med søsterpartier i nabolandene. For så vidt som den nye politik havde gamle rødder $\mathrm{i}$ partiet, var den egentlig også blot udtryk for kontinuitet. Indenrigspolitisk taktik kom langt nede på listen over motiverne bag kursskiftet.

Kommentar: Man kan opstille en alternativ forklaring på det socialde- 
mokratiske kursskifte, som jo først for alvor slog igennem i 1982 nogle måneder efter, at partiet var gået $\mathrm{i}$ opposition. Den er uhyre ligetil, men også så rent taktisk, at ingen socialdemokrat kan stå ved den offentligt, og at alle akademiske analytikere lige siden har slået knuder på sig selv for at argumentere uden om den. Ikke desto mindre var den også mange udenlandske iagttageres foretrukne forklaring.

Den lyder således: Da partiet i opposition ikke kunne profilere sig på økonomien, som det selv havde kørt ud "på afgrundens rand", valgte det at bruge sikkerhedspolitikken. På dette ene område kunne det regne med tøvende støtte fra De Radikale, som på andre områder støttede regeringen, og jublende støtte fra venstrefløjen. På dette ene område kunne det med et beskedent flertal i ryggen genere regeringen og måske vinde nye vælgere blandt neutralistisk indstillede danskere. Det krævede blot, at partiet afgørende vendte ryggen til den alliancepolitik, det siden 1949 havde taget ansvar eller medansvar for.

Konfrontationen i Folketinget eskalerede, og da regeringen endelig i foråret 1988 tog et valg på "anløbssagen”, ønskede De Radikale ikke længere at lade sig bruge. Det "alternative" sikkerhedspolitiske flertal ophørte med at eksistere, og et mærkeligt og ubehageligt kapitel i Danmarks udenrigspolitiske historie var slut. Det er måske ikke overra- skende, at kommentatorer med tilknytning til eller sympati for det daværende "alternative" flertal mener, at det mærkelige og ubehagelige var, at regeringen ikke meget hurtigere tog et valg på spørgsmålet. Men for regeringen var den skadeskudte økonomi umiddelbart det største sikkerhedsproblem for Danmark, og derfor gjorde den ikke "fodnoterne" til et kabinetsspørgsmål før i 1988, og derfor ville De Radikale i øvrigt ikke stemme for en mistillidsdagsorden.

Det har givet anledning til uberettigede påstande om, at heller ikke regeringen tog alliancepolitikken alvorligt. Regeringen regnede blot ikke med, at et hurtigt valg ville forbedre forholdene, og den regnede med at kunne "holde fortet" $i$ alliancen med uformelt diplomati og ved at passe det daglige forsvarssamarbejde. I øvrigt sluttede Socialdemokratiet sig igen til den sikkerhedspolitiske hovedstrøm efter Murens fald, og efter yderligere tre år genvandt det regeringsmagten og førte derefter en aktivistisk udenrigs- og ikke mindst forsvarspolitik i samarbejde med vore allierede i NATO og i FN-regi.

\section{Alliancen og indflydelsen}

Konklusion: Vore allierede var ikke glade for fodnoterne; men de slog sig til tåls med, at en alliancetro regering stadig havde hånden på roret, at vi stadig stillede op i det militære samarbejde, at det nok i bund 


\section{LITTERATUR Kold krig}

og grund drejede sig om dansk indenrigspolitik, og at det i den store sammenhæng alligevel ikke gjorde meget fra eller til, hvad lille Danmark sagde. Der spores således ingen konsekvenser af Danmarks officielle særstandpunkter, og tab af vor i forvejen beskedne prestige og indflydelse var begrænset til det forsvars- og sikkerhedspolitiske miljø.

Sovjetunionen var ganske vist fornøjet, men regnede ikke med at kunne få noget ud af den danske enegang. For "samlet set var Danmark ikke en forbeholden allieret, men blev både politisk og militært integreret mere og mere i NATO og langt overvejende af sine partnere opfattet som et loyalt alliancemedlem.

Kommentar: Det er da klart, at Danmark i 1980'erne ikke betød og stadig ikke betyder meget i den store sammenhæng. Men i den kolde krigs vanskelige slutspil lagde vi vort lille lod i den forkerte vægtskål. Det havde ganske rigtigt ikke målelige konsekvenser for vort renommé som fx eksportland (denne lidet overraskende observation finder udredningen anledning til at fremhæve). Men vore allierede, hvis militære støtte vort forsvar afhang af, var skuffede og irriterede, og USA fandt det nødvendigt for én gangs skyld at anbringe en professionel topdiplomat som ambassadør i København.

Ambassadør Todman, som Svend Auken havde mindst én ubehagelig samtale med, har ikke ladet sig interviewe. I stedet har man spurgt hans daværende medarbejder Peter Swiers. Men Swiers mener sig fejlfortolket, bl.a. fordi man har valgt ikke at tage hensyn til en mail, som han sendte efter interviewet med en præcisering af, at USA faktisk så med alvor på den danske enegang.

Disse og flere ubehagelige kendsgerninger om Danmarks samarbejde med vore allierede i den afgørende sidste fase af den kolde krig forsvinder i udredningens samlede konklusion om Danmark som allieret, som gælder hele forløbet fra 1949 til 1991. Er det en analytisk gevinst at slå alt sammen og tage gennemsnittet, eller er det - endnu - et forsøg på at bagatellisere problemerne med det sikkerhedspolitiske flertals fodnoter?

Man kan i øvrigt formode, men ikke bevise, at den socialdemokratiske ledelses taktiske manøvrer i 1980'ernes udenrigs- og sikkerhedspolitik, som inkluderede et nej til EU's indre marked, bidrog til, at Socialdemokratiet som det eneste parti måtte opleve, at et flertal af dets vælgere i juni 1992 stemte imod partilinjen, som var en anbefaling af et ja til EU-traktaten.

Følgen blev, at vi til i dag har måttet trækkes med bl.a. et forsvarsforbehold, som ingen tør påstå tjener landets interesser på nogen som helst måde. Det koster altså indflydelse og ikke kun i EU.

Forsvarets Efterretningstjeneste 
Udrederne har haft adgang til flere tusinde sider efterretningsoversigter fra Forsvarets Efterretningstjeneste (FE). De synes i det store og hele tilfredse med kvaliteten af det omfattende materiale, og de trækker kraftigt på det. Men de skriver også, at "det fremlagte materiale - ud over sine faktuelle oplysninger om den $\emptyset$ stlige trussel - kaster lys over den ideologi og omverdensforståelse, som var bærende for de danske efterretningstjenesters arbejde".

FE's "ideologi" var, at man som loyale embedsmænd skulle løse de opgaver, man fik pålagt af regeringen, og at der aldrig måtte kunne opstå tvivl om tjenestens troværdighed. Når politikerne årligt bevilgede trecifrede millionbeløb for at få gjort varslingen så præcis som mulig og især så hurtig som mulig, skulle de ikke i en krise være nødt til at bruge tid på at overveje, om FE nu leverede sit bedste bud eller fx bare snakkede dem efter munden. Af samme grund blev der i øvrigt heller aldrig gjort forsøg på at presse bestemte konklusioner ud af FE.

Men det er jo nok ikke den type "ideologi", den citerede passus i udredningen sigter til. Den er derimod en forblommet antydning af, at FE så på sin opgave gennem et ideologisk filter og en - indskrænkende omverdensforståelse, at FE kort sagt forholdt sig usagligt og uprofessionelt til sit arbejde. Det er en ganske grov insinuation, som man burde have begrundet nærmere eller udeladt.

FE's primære opgave, som var defineret af regeringen, var at kunne varsle om et eventuelt sovjetisk angreb rettet mod os eller vore naboer og allierede. Til det formål måtte man opbygge og vedligeholde et umådeligt omfattende og detaljeret "normalbillede" af den potentielle angriber: hans militære styrker, deres placering, bevægelser, uddannelse og øvelsesmønstre, men også hans tekniske formåen, økonomiske situation og politiske forhold og ytringer. Et normalbillede er nødvendigt for at kunne opdage og fortolke afvigelser. De allerfleste vil kun give anledning til justering af normalbilledet; men nogle kan være indikationer på en unormal og evt. truende udvikling.

FE havde selvfølgelig ingen interesse $i$ at fremstille forholdene værre eller bedre, end de var. FE løste sin opgave uafhængigt og professionelt, og arbejdet var et nødvendigt grundlag for selvstændige danske beslutninger; men det nød også stor respekt blandt vore allierede og var måske et af de væsentligste - og mindst kendte - danske bidrag til NATOs fælles forsvar.

\section{Ubåde i skærgården}

Det er i fuld overensstemmelse med kommissoriet, at udredningen interesserer sig for den sovjetiske ubådsaktivitet i svensk farvand. FE kritise- 


\section{LITTERATUR Kold krig}

res for at udelade en række spørgsmål om den strandede ubåds opgaver, "som i dag forekommer naturlige". Udrederne formoder, at det "beroede på en vis uvilje mod at blotlægge sin egen usikkerhed og manglende viden i en efterretningsoversigt, der gik ud til et stort antal modtagere". Det lyder jo ikke godt; men næste sætning, som i sammenhængen måske også skal forstås som kritik, vil denne anmelder tillade sig at opfatte som et ridderslag til FE:

"Der er i disse oversigter en klar tendens til at prioritere fakta og ny viden på bekostning af diskussioner af muligheder."

Netop! FE skrev helst kun, hvad man kunne stå ved:.Der var en ubåd langt inde i forbudt område. Det var næsten en umulighed, at den skulle være kommet derind ved en fejltagelse - om end det selvfølgelig var en fejl, at den gik på grund på vej ud igen. Den var sovjetisk. Den var højst sandsynligt bestykket med kernevåben. Og på dette solide grundlag konkluderede man meget naturligt, at såvel operationer i skærgården som kernevåben på Whiskeyklasse ubådene i den sovjetiske Østersøflåde nok var en del af normalbilledet.

Alle forklaringer har lige siden beroet på spekulationer; for desværre turde svenskerne ikke slæbe ubåden i dok i Karlskrona, skille den ad og afhøre hver eneste mand ombord, som de kunne have gjort med al folkeret i ryggen. Det ville russerne uden tvivl selv have gjort, hvis de havde fået serveret en svensk eller anden fremmed ubåd på samme vis i Riga-bugten eller den estiske skærgård, og så ville man med stor sikkerhed have fundet ud af, hvad det hele gik ud på. I stedet gik svenskerne i selvforhandling, som endte med betingelsesløs udlevering af ubåden efter ti dage, og de har diskuteret sagen lige siden.

Et godt, men sjældent set bud på en forklaring på den sovjetiske aktivitet kunne være, at ubådene øvede sig i at forlægge til og operere fra den svenske skærgård, hvor det er langt lettere at gemme sig end på den baltiske kyst. Den er enkel og kan begrundes operativt, men er måske ikke så spændende som teorierne om efterretningsoperationer og forberedelser af sabotage.

Udrederne gætter i øvrigt på, at grunden til, at FE ikke gjorde meget ud af efterretningsaspektet nok var, at danske myndigheder jo selv anvendte ubåde til indhentning af efterretninger. Som denne spekulation er anbragt i sammenhængen, synes den at insinuere, at danske ubåde nok også sneg sig ind i andre landes territorialfarvand. Det uddybes ikke nærmere; men udrederne synes væsentlig mindre interesserede $\mathrm{i}$ de sovjetiske operationer end i spinkelt begrundede formodninger om, at NATO-lande efter den sovjetiske stranding gennemførte hyppige operationer i svensk farvand i maskepi med den svenske flåde bag om 
ryggen på den svenske regering. Skulle dette have noget på sig, må disse operationer dog vel betegnes som i en eller anden forstand venligtsindede. Det var de sovjetiske ikke, og sådan blev de bestemt heller ikke opfattet af den svenske offentlighed.

\section{Det forsvundne fjendebillede}

Udredningens vægtning af ubådsaffærens forskellige sider falder smukt i tråd med dens fokusering på den amerikanske "sejrsstrategi", der dominerede den kolde krigs sidste fase, indledt af præsident Carter og videreført og forstærket af præsident Reagan. Behandlingen af "Sejrsstrategien" og diskussionen mellem USA og de europæiske allierede skygger som næunt noget for analysen af, hvad Sovjetunionen foretog sig.

Man kommer i den forbindelse til at tænke 1980'ernes store officielle analyse af Danmarks sikkerhedspolitiske situation Dyvig-rapporten. Den kom i 1985, og karakteristisk for tidspunktet handlede den stort set udelukkende om forholdet til vore allierede. Forholdet til Sovjetunionen blev ikke analyseret og næsten ikke omtalt, hvilket fik Niels Erik Rosenfeldt til at skrive en kronik i Berlingske Tidende om "Fjendebilledet der helt forsvandt" og Det Udenrigspolitiske Selskab til at organisere et stort og gennem mange måneder forberedt seminar i november 1986 med nogle af tidens bedste Sovjetkendere om "Sovjetunionen og dansk sikkerhedspolitik" for at fylde hullet ud.

Udredningen vurderer da også, at “det i de urolige 1980'ere var 'alliancespillet', ikke 'modstanderspillet', der var i centrum". Det kunne jo fx hænge sammen med, at Folketingets sikkerhedspolitiske flertal i "de urolige 1980'ere" ikke var meget for at udpege nogen egentlig modstander, og uden en defineret modstander glider 'modstanderspillet' jo nødvendigvis i baggrunden. Men hvis det dominerende 'spil' i virkeligheden var 'magtspillet' i Folketinget, glider jo også 'alliancespillet' i baggrunden som et sideshow i den danske indenrigspolitik, og så mangler der en væsentlig dimension i udredningens fine modeller.

\section{Oversete indikationer}

Når den kolde krig kunne ende så hurtigt og så fredeligt, skyldtes det ikke kun, at Sovjetunionen brat skiftede kurs og søgte samarbejde i stedet for konfrontation. Det er i sammenhængen, og i udredningen, et noget overset faktum, at Vesten helt umiddelbart var - og derfor vel hele tiden må have været - klar til at tage imod en udstrakt hånd. Er det ikke en indikation fra 'slutspillet' på, at hovedansvaret for den kolde krig må placeres på Sovjetunionen?

En indikation på det samme fra ‘åbningsspillet' kan man få ved at gå 


\section{LITTERATUR Kold krig}

til en trykt og publiceret dansk primærkilde af høj lødighed, som tilsyneladende ikke optræder i nogen af koldkrigshistoriernes litteraturlister, så lad os slå et slag for den her: Erik Ib Schmidt, 30 Aars kommunistisk Politik, 1948 (286 s.).

Han var medlem af DKP fra 1931, til han meldte sig ud i 1939. Han arbejdede i længere perioder for partiet i Tyskland, Frankrig og Moskva og blev leder af DKU. Han havde således et yderst indgående personligt kendskab til kommunistisk og sovjetisk politik. Han var en knivskarp analytiker og særdeles velformuleret og fik senere en lysende karriere i centraladministrationen som en af sin tids mest betydelige departementschefer.

Bogen udkom efter den kommunistiske magtovertagelse i Prag, og den pegede på, hvorfor og hvorledes Sovjetunionen og kommunismen udgjorde en alvorlig fare for Vesteuropas demokratier.

\section{Anbefales til læsning}

Udredningen vil stå som en uomgængelig materialesamling om perioden. Informationsmængden er overvældende, men til at finde rundt i. Mængden af overvejelser, vurderinger, skøn, gætterier og insinuationer er også stor, og udredningen har for længst bevist, at den er et fortræffeligt udgangspunkt for livlige debatter om den kolde krig. Og i betragtning af, hvor mange bøger om besættelsen, der fortsat skrives, bør man nok gå ud fra, at den kolde krig vil blive analyseret og diskuteret i endnu mange år, bl.a. fordi der forhåbentlig efterhånden vil blive frigivet højst relevant arkivmateriale, som endnu ikke er tilgængeligt.

Man kunne have ønsket sig bind 4 udvidet til en solid monografi om emnet med bind 1-3 i let slanket udgave som bilagsbind. Som det nu er, kan det varmt anbefales at læse bind 4 og evt. nøjes med lejlighedsvise ekskursioner i bind 1-3, hvor mængden af træer skygger lidt for skoven. Overblikket over den kolde krigs sidste turbulente tredjedel i dansk perspektiv henter man måske bedst i Nikolaj Petersens velskrevne bind 6 af Dansk Udenrigspolitiks Historie.

Det bør ikke bebrejdes en anmelder i Udenrigs, at han på falderebet også slår et slag for dette tidsskrifts forløber Fremtiden, som udkom fra 1945 til 1987 og videreførtes som Udenrigs fra 1988. Det optræder ikke blandt udredningens benyttede tidsskrifter - med mindre der skulle være tale om det Fremtiden, som oplyses udgivet af De Radikale - så lidt som næsten alle Det Udenrigspolitiske Selskabs andre udgivelser fra perioden. De kan alle lånes på selskabets bibliotek. 